УДК 796.412-055.2

DOI https://doi.org/10.26661/2663-5925-2020-1-07

\title{
ОБГРУНТУВАННЯ ЗМІСТУ СУЧАСНИХ ВИДІВ ОЗДОРОВЧОЇ АЕРОБІКИ ТА МЕНТАЛЬНОГО ФІТНЕСУ ДЛЯ ЖІНОК ПЕРШОГО ЗРІЛОГО ВІКУ
}

\author{
Синиця Т. О. \\ кандидат наук з фізичного виховання та спорту, \\ старший викладач кафедри фізичної культури та спорту \\ Національний університет «Полтавська політехніка імені Юрія Кондратюка» \\ пр. Першотравневий, 24, Полтава, Украӥна \\ orcid.org/0000-0002-6971-0161 \\ sinicata@ukr.net \\ Синиця С. В. \\ кандидат наук з фізичного виховання та спорту, \\ доиент кафедри теорії та методики фізичної культури адаптивної \\ та масової фізичної культури \\ Полтавський національний педагогічний університет імені В. Г. Короленка \\ вул. Остроградського, 2, Полтава, Украӥна \\ orcid.org/0000-0001-7965-8355 \\ sinicasv@ukr.net
}

\begin{abstract}
Ключові слова: жінки, перший зрілий вік, оздоровча аеробіка, ментальний фітнес, програма.
\end{abstract}

На сьогодні є багато засобів залучення населення до здорового способу життя, зокрема до регулярних фізкультурно-оздоровчих занять. Одним із найпопулярніших видів рухової активності жінок є заняття з аеробіки. Цей вид рухової активності стрімко розвивається й має значну кількість прихильників серед людей різного віку від дошкільників до осіб похилого віку. Також користується популярністю порівняно новий вид - ментальний фітнес. Цей вид фітнесу грунтується на досягненні психічної гармонії під час виконання вправ. До нього відносять заняття з пілатесу, стретчингу, фітнес-йоги, у-шу тощо. Ураховуючи те, що оздоровча аеробіка та ментальний фітнес охоплює багато видів занять, для встановлення найпопулярніших із них було проведено анкетування. Результати опитування жінок першого зрілого віку показали, що найбільш популярними видами оздоровчої аеробіки є заняття 3 використанням обладнання $(27,2 \%)$, дещо менше прихильників у видах силової аеробіки $(21,5 \%)$, танцювальної аеробіки $(17,1 \%)$ та ментального фітнесу (14,8\%). Решта, 19,4\% респондентів, розподілили свої уподобання між класичною, аеробікою у водному середовищі, з елементами бойових мистецтв та циклічними видами аеробіки.

Ураховуючи результати анкетування, досвід учених та дані методичних напрацювань, було розроблено комплексну програму з оздоровчої аеробіки та ментального фітнесу, яка охоплювала понад 15 видів оздоровчої аеробіки та 4 види ментального фітнесу. У програмі використовувались заняття двох видів: монозаняття з окремих видів оздоровчої аеробіки або ментального фітнесу та комбіновані, які поєднували декілька видів оздоровчої аеробіки та ментального фітнесу на одному занятті.

Комбіновані заняття були загальноприйняті, тобто такі, які вже сформовані (мікс 20/20/20, фітбол-аеробіка, Кік-СВ та аква-формінг), а також ті, які будувались 3 урахуванням популярності видів оздоровчої аеробіки та аналізу їх впливу на різні системи організму й фізичні якості тих, хто тренується.

У процесі занять за комплексною програмою з оздоровчої аеробіки та ментального фітнесу проводились дослідження рівня фізичної підготовленості жінок, які підтвердили іï ефективність. 


\title{
EXPLANATION OF THE CONTENT OF MODERN KINDS OF RECREATIONAL AEROBICS AND MENTAL FITNESS OF THE WOMEN'S THE FIRST MATURE AGE
}

\author{
Synytsya T. 0. \\ Candidate of Sciences in Physical Education and Sports, \\ Assistant Professor at the Department of Physical Culture and Sports \\ National University "Yuri Kondratyuk Poltava Polytechnic" \\ Pershotravneva avenue, 24, Poltava, Ukraine \\ orcid.org/0000-0002-6971-0161 \\ sinicata@ukr.net \\ Synytsya S. V. \\ Candidate of Sciences in Physical Education and Sports, \\ Senior Lecturer at the Department of Theory and Methods of Physical Culture of Adaptive \\ and Mass Physical Culture \\ Poltava V. G. Korolenko National Pedagogical University \\ Ostrogradskoho str., 2, Poltava, Ukraine \\ orcid.org/0000-0001-7965-8355 \\ sinicasv@ukr.net
}

Key words: women's, the first mature age, health aerobic, mental fitness, program.
Today there is a large numerous of ways to involve the population in a healthy lifestyle, including regular physical culture and health classes. One of the most popular types of physical activity for women is aerobics. This type of physical activity is developing rapidly and has a significant number of supporters among people of all ages from preschoolers to the elderly. Also a relatively new kind, which is called mental fitness, is popular. This type of fitness is based on achieving mental harmony during exercising. It includes classes in Pilates, stretching, fitness yoga, u-shu and more.

Taking into account that health aerobics and mental fitness include a large number of types of exercises, a survey was conducted to identify the most popular of them. The results of the survey of women of the first mature age showed that the most popular types of health aerobics are classes with the use of equipment $(27.2 \%)$, slightly less supporters in the types of strength aerobics (21.5\%), dance aerobics (17.1\%) and mental fitness $(14.8 \%)$. The rest, $19.4 \%$ of respondents, divided their preferences between classical, aerobics in the aquatic environment, with elements of martial arts and cyclic types of aerobics. Taking into account the results of the questionnaire, the experience of scientists and methodological data, a comprehensive program on health aerobics and mental fitness was developed, which included more than 15 types of health aerobics and 4 types of mental fitness. Program used two types of classes: mono-classes on certain types of health aerobics or mental fitness and combined, which combined several types of health aerobics and mental fitness in one class.

Combined classes were common, it means those that have already been formed (mix 20/20/20, fitball-aerobics, Kick-SV and aqua-forming), as well as those that were built taking into account the popularity of health aerobics and analysis of their impact on different body systems and physical qualities of those involved.

In the course of classes on a comprehensive program of health aerobics and mental fitness, studies were conducted on the level of physical fitness of women, which confirmed its effectiveness. 
Постановка проблеми. Аналіз науково-методичної літератури свідчить, що на сучасному етапі розвитку суспільства спостерігається стрімке погіршення рівня здоров'я населення України, що, на думку фахівців, $є$ наслідком недостатньої рухової активності внаслідок технічного прогресу $[7 ; 14]$. Ця проблема стосується людей різного віку і статі, від школярів і студентів до жінок 3-50 років і старше, у яких здебільшого сидяча робота й малорухомий спосіб життя [4]. Рухова активність $є$ універсальним засобом покращення здоров'я, профілактики надмірної маси тіла та ожиріння та дозволяє зменшити ризик виникнення різних захворювань та депресії, а також сприяє збереженню високої працездатності протягом життя [9].

На сьогодні $є$ багато засобів залучення населення до здорового способу життя, зокрема до регулярних фізкультурно-оздоровчих занять. Великою популярністю серед жінок користуються сучасні види оздоровчої фізичної культури, зокрема різноманітні види оздоровчої аеробіки: степ-аеробіка, фітбол-аеробіка, танцювальні види аеробіки (латина, стріп-денс, хіп-хоп, афро-джаз тощо), шейпінг, калланетик, пілатес тощо [5]. Має своїх прихильників порівняно новий вид - ментальний фітнес. Цей вид фітнесу грунтується на досягненні психічної гармонії під час виконання вправ. До нього відносять заняття 3 пілатесу, стретчингу, фітнес-йоги тощо.

Багато науковців працювали над дослідженням впливу різних видів оздоровчої аеробіки на різні системи організму жінок. Так, О. Шишкіна, I. Бейгул [13] досліджували зміни функціональних показників жінок 25-30 років під впливом занять фітнесом. Корекцією маси та складу тіла жінок 21-35 років із використанням засобів оздоровчого фітнесу вивчала О.О. Мороз [10]. Т.П. Козій, О.О. Тарасова [8] присвятила праці впливу занять аква-аеробікою та шейпінгом на антропометричні показники жінок середнього віку. О.Ю. Лядська [9] розкрила основи оздоровчих занять із фітболом для жінок першого зрілого віку. Р.В. Бибик [3] дослідила праці науковців щодо сучасних систем оздоровлення жінок, включно з оздоровчим фітнесом.

Проте праці розкривають зміст окремих видів оздоровчої аеробіки на різні системи організму жінок. Недослідженим залишається питання обгрунтування програми занять різними видами оздоровчої аеробіки в комплексі 3 ментальним фітнесом.

Мета статті - розкрити зміст комплексної програми занять із сучасних видів оздоровчої аеробіки та ментального фітнесу.

Виклад основного матеріалу дослідження. Рух - це біологічна потреба організму, яка віді- грає важливу роль у формуванні його життєдіяльності і створює сприятливі передумови адаптації до несприятливих зовнішніх чинників. Бажання займатись фізичними вправами може виникати в жінок, які вже займаються різними видами рухової активності або лише хочуть, але не мають часу чи вагомого мотиву до початку занять.

У процесі дослідження було проведено анкетування жінок першого зрілого віку (298 респондентів) із метою з'ясування їх ставлення та встановленням пріоритетних видів рухової активності.

Таким чином, бажання займатись фізичними вправами виявили 92,8\% опитаних жінок. Це доводить, що вони обдумано та усвідомлено турбуються про стан власного здоров'я. Водночас $7,2 \%$ опитуваних зазначили, що не мають такої потреби.

Визначення пріоритетних видів рухової активності здійснювалось шляхом їх розташування респондентами за рейтингом (від найбільш цікавих до менш актуальних). Пропонували обирати серед таких видів, як: оздоровча аеробіка, спортивні ігри (футбол, баскетбол, волейбол), кросовий біг або ходьба, їзда на велосипеді, плавання й туризм. Iз коментарів респондентів це можна пояснити тим, що запропоновані види рухової активності $€$ для них цікавими та привабливими, проте заняття 3 оздоровчої аеробіки вони вважають більш дієвими, доступними та популярними, тому й займаються нею, але, не обов'язково віддають перше місце цим заняттям. Таким чином, найпопулярнішим видом рухової активності для жінок першого зрілого віку є оздоровча аеробіка, оскільки $62,4 \%$ респонденток поставили ії на чільне місце; $16,7 \%$ жінок надали перевагу спортивним іграм; для 9,5\% опитуваних найбільш привабливим $є$ плавання; 6,7\% анкетованих обрали кросовий біг та ходьбу; $2,8 \%$ віддали перевагу туризму; $1,9 \%$ їзді на велосипеді. Другорядними видами рухової активності респонденти вважають: 37,6\% - оздоровчу аеробіку; $19,5 \%$ - плавання; $14,3 \%$ - їзду на велосипеді; $10,9 \%$ - кросовий біг та ходьбу; $10,5 \%$ - туризм; 7,2\% - спортивні ігри. На третьому місці для 22,8\% жінок знаходиться плавання; для $21,9 \%$ - кросовий біг та ходьба; для $20,5 \%$ - туризм; для $18,6 \%$ - їзда на велосипеді, для $16,2 \%$ - спортивні ігри.

Оскільки оздоровча аеробіка охоплює багато напрямів та видів, попередніми дослідженнями [15] було визначено їх популярність.

Опитування жінок першого зрілого віку показало, що найбільшою популярністю користуються види оздоровчої аеробіки 3 використанням різного обладнання $(27,2 \%)$, а саме степ-аеробіка та фітбол-аеробіка. Дещо менше прихильниць виявилось у видів силової аеробіки $(21,5 \%)$, які відзначили для себе скульптуру тіла. 
Танцювальні види аеробіки обрали 17,1\% анкетованих і віддали перевагу таким видам занять, як латина (сальса) та пол-денс. Ментальний фітнес виокремили 14,7\% опитуваних, які більшою мірою обирали фітнес-йогу, пілатес та стретчинг. Менш популярними видами виявились класична аеробіка, аеробіка у водному середовищі, з елементами бойових мистецтв та циклічна аеробіка, які обрали 19,4\% респондентів [15].

На основі аналізу даних анкетування попередніх напрацювань дослідників та власного досвіду було побудовано комплексну програму 3 оздоровчої аеробіки та ментального фітнесу.

Заняття за комплексною програмою з оздоровчої аеробіки та ментального фітнесу проводились три рази на тиждень (понеділок, середа та п'ятниця). 3 огляду на рекомендації фахівців [11] щодо рівня інтенсивності занять протягом тижня щопонеділка заняття були комбінованими, тобто містили види оздоровчої аеробіки, силові блоки та ментальний фітнес. Щосереди проводились найбільш інтенсивні заняття, в яких використовувались степаеробіка, джампінг, танцювальна аеробіка. Заняття щоп’ятниці складались або виключно із вправ ментального фітнесу, або були комбінованими, але 3 більш тривалим, ніж у понеділок, застосуванням вправ силової аеробіки та ментального фітнесу.

Усі заняття тривали 60 хвилин і традиційно складались із підготовчої частини - $12-15 \%$ часу заняття; основної - 70-80\% і заключної - 8-10\% [6].

Аеробні заняття охоплювали класичну аеробіку, танцювальну, степ-, фітбол-аеробіку, з еле- ментами бойових мистецтв та у водному середовищі. Вони становили підготовчу та основну частини заняття й були спрямовані на розвиток серцево-судинної та дихальної систем, значно впливали на зниження ваги тіла і сприяли зняттю можливих стресових напружень.

Під час складання комплексної програми 3 оздоровчої аеробіки та ментального фітнесу та проведення занять, чітко визначалась тривалість окремих видів оздоровчої аеробіки, силового блоку та ментального фітнесу на занятті (рис. 1).

Під час дослідження у змісті комплексної програми $з$ оздоровчої аеробіки та ментального фітнесу використовувались комбіновані заняття двох видів: загальноприйняті, тобто такі, які вже сформовані (мікс 20/ 20/ 20, фітбол-аеробіка, Кік-СВ та аква-формінг), а також ті, які будувались з урахуванням популярності видів оздоровчої аеробіки та аналізу їх впливу на різні системи організму й фізичні якості тих, хто тренується:

- класична аеробіка/силовий блок стретчинг;

- мікс 50\%/50\% (класична аеробіка або 3 елементами бойових мистецтв/силовий блок/ стретчинг);

- джампінг/силовий блок/стретчинг.

Таке різноманіття поєднання видів оздоровчої аеробіки та ментального фітнесу на заняттях сприяло корекції зовнішніх форм тіла та поступовому зниженню ваги, а також тренуванню м'язової системи тих, хто тренується, розвитку силових здібностей та витривалості до виконання більших за величиною навантажень.

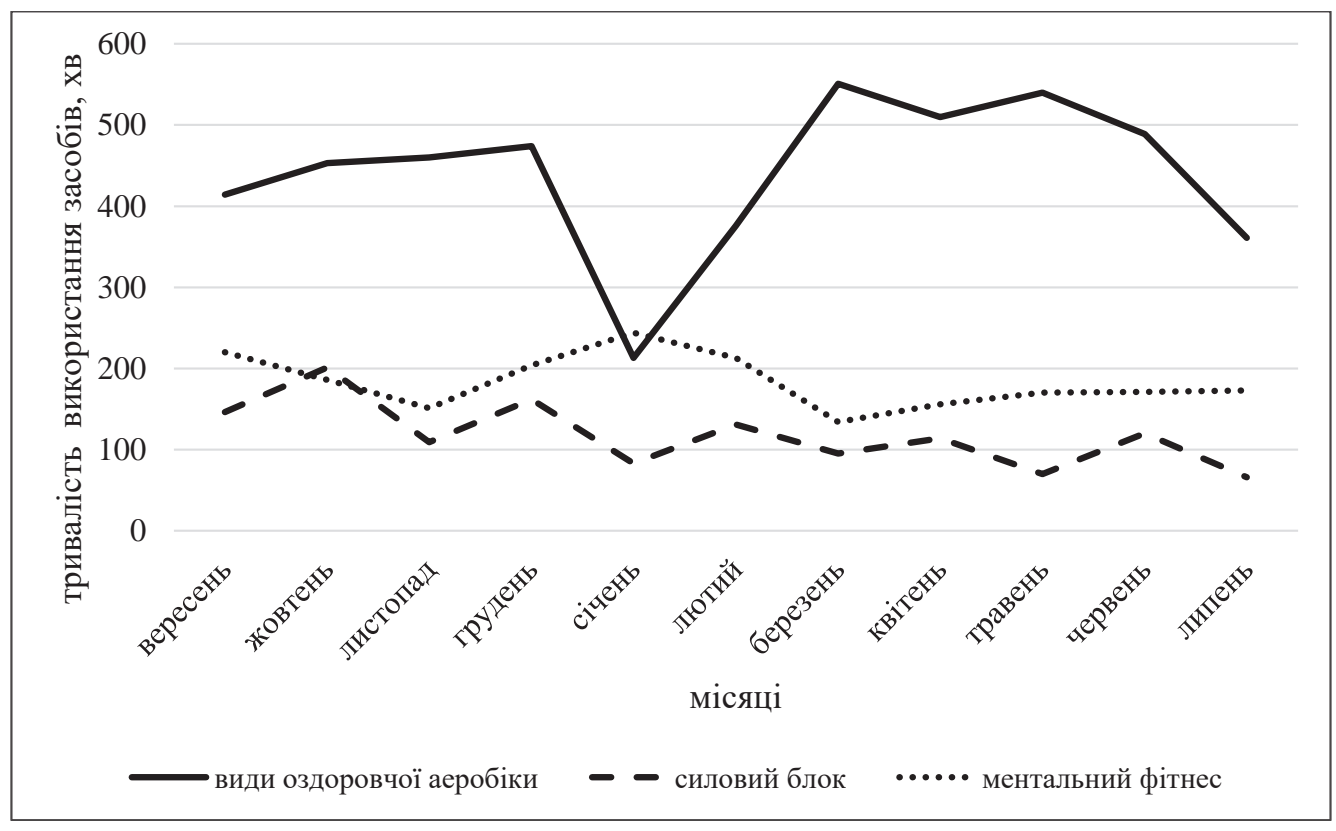

Рис. 1. Планування розподілу занять комплексної програми з оздоровчої аеробіки та ментального фітнесу за часом використання засобів 
Ментальний фітнес використовували в комбінованих заняттях - блок тривалістю до 20 хвилин, та як монозаняття 3 пілатесу та фітнес-йоги тривалістю 60 хвилин. Вправи зі стретчингу застосовувались у заключній частині майже у всіх заняттях комплексної програми 3 оздоровчої аеробіки та ментального фітнесу. В підготовчій частині занять вправи стретчингу сприяли підготовці та мобілізації м'язів до виконання великих навантажень, у заключній частині - допомагали розслабитись та зменшити можливість прояву відчуття м'язового болю. Використовувався активний, пасивний та змішаний стретчинг. Ці вправи проводились самостійно на килимках, у двійках та трійках, де збільшення амплітуди відбувалось шляхом дій партнера. Така організація виконання вправ стретчингу, окрім прямого впливу на організм, сприяла збільшенню амплітуди рухів, підвищенню емоційного фону занять та настрою в тих, хто займаються. На заняттях, які містили блок «здорова спина», також застосовувались вправи стретчингу, що сприяло профілактиці викривлень хребта.

Комплексна програма з оздоровчої аеробіки та ментального фітнесу для корекції фізичного стану жінок першого зрілого віку охоплювала багато занять оздоровчої аеробіки 3 використанням обладнання. Це обгрунтовано результатами анкетування жінок першого зрілого віку згідно з якими аеробіку 3 використанням обладнання виокремили $27,2 \%$ респондентів. Окрім цього, останнім часом з'являється багато новітнього обладнання, яке підвищує зацікавленість жінок заняттями. Тож під час упровадження комплексної програми 3 оздоровчої аеробіки та ментального фітнесу проводились заняття зі степ-аеробіки, фітбол-аеробіки, джампінгу, у процесі яких використовувались бодібари, гантелі, терабанди, мотузки.

Заняття зі степ-аеробіки виявились найпопулярнішими серед опитуваних, що було враховано під час розробки комплексної програми з оздоровчої аеробіки та ментального фітнесу. Навантаження під час занять степ-аеробікою середнс та вище середнього, тому цей вид занять починали проводити із другого тижня впровадження комплексної програми з оздоровчої аеробіки та ментального фітнесу. Враховуючи те, що протягом тижня навантаження повинно поступово зростати на його початку, бути найбільшим у середині та поступово знижуватись наприкінці [11], заняття зі степ-аеробіки проводились щосереди. На початкових етапах комплекси вправ степ-аеробіки були на базовому рівні за складністю, поступово складність їх підвищувалась до першого рівня на етапі набуття фізичної форми. На третьому місяці занять за комплексною програмою з оздоровчої аеробіки та ментального фітнесу ті, хто займаються, досягали другого рівня складності занять зі степ-аеробіки, що відобразилось у швидкості розучування комплексів вправ та виконанні їх під музичний супровід різного темпу. Заняття зі степ-аеробіки другого рівня складності передбачали розучування комбінації кроків на двох степ-платформах, які стоять поруч - дабл-степ, а також виконання комплексу вправ із використанням елементів бойових мистецтв. Це підвищило як координаційну складність заняття, так і навантаження, й емоційний фон у тих, хто займаються.

Окрім занять зі степ-аеробіки, жінки першого зрілого віку обрали для себе заняття джампінгом на батутах. Це високоінтенсивний вид оздоровчої аеробіки, тому його було включено до програми iз третього місяця відвідування занять, на етапі набуття фізичної форми. Це порівняно новий вид занять, тому його впроваджували в комплексній програмі з оздоровчої аеробіки та ментального фітнесу у вигляді презентації. Заняття джампінгом передбачає, в основному, виконання рухів на основі стрибків, тому це були комбіновані заняття, які поєднувались із силовими блоками, а саме: вправами з бодібарами та гантелями.

Окрім джампінгу, протягом впровадження комплексної програми з оздоровчої аеробіки та ментального фітнесу проводились презентації таких занять: гоу-гоу, пілатес, Кік-аеробіки, даблстеп. Такі заняття проходять на високому емоційному фоні із запрошенням гостей (тренерів, тих, хто замаються в інших групах та їх близьких). Перелічені види занять $є$ новими для жінок експериментальної групи. Після занять із дабл-степ у тих, хто тренується, спостерігалось емоційне піднесення, тому можна зробити висновок, що цей вид занять користується популярністю. Прихильність жінок до заняття 3 дабл-степ не викликає сумнівів, оскільки підтверджує результати анкетування популярності видів оздоровчої аеробіки. На відміну від заняття 3 у-шу, в якого виявилось менше прихильників. Мала прихильність до занять із включенням у-шу серед відвідувачів пояснюється тим, що східні напрями занять $є$ специфічними та не надто активними, тому ті, хто займаються, віддавали більшу перевагу або більш відомим їм видам занять (пілатес, фітнес-йога), або аеробним та більш інтенсивним заняттям.

Серед нестандартних форм організації та проведення занять за комплексною програмою з оздоровчої аеробіки та ментального фітнесу, окрім презентацій, проводились фітнес-марафони. Фітнес-марафон проводився один раз у кожному періоді впровадження комплексної програми 3 оздоровчої аеробіки та ментального фітнесу на етапі активного відпочинку. В межах фітнес-марафону проводилось два види оздоровчої аеробіки гоу-гоу та джампінг та один вид ментального фітнесу - бодіфлекс. До проведення фітнес-марафону 
були залучені інструктори 3 інших фітнес-установ м. Полтави. Заняття проводились за участю інших інструкторів, які будували комплекси вправ з урахуванням комплексної програми з оздоровчої аеробіки та ментального фітнесу, а проводили їх у власному стилі, що певною мірою впливало на координаційні здібності тих, хто займаються.

Танцювальні види оздоровчої аеробіки також користуються популярністю серед жінок першого зрілого віку. Види, які виокремили більшість тих, хто займаються (латина, гоу-гоу, хіп-хоп, фітнес белліденс, афро-денс, рок-н-рол, диско-денс) були включені до комплексної програми з оздоровчої аеробіки та ментального фітнесу. Виконання стилізованих рухів танцювальної аеробіки вимагає певного рівня підготовленості, тому їх було включено до програми із сьомого дня тренувань. Згідно з результатами анкетування щодо популярності видів оздоровчої аеробіки та ментального фітнесу латину обрала більшість респондентів. Тому ії першою та частіше, ніж інші види танцювальної аеробіки, було включено до комплексної програми з оздоровчої аеробіки та ментального фітнесу. 3 одинадцятого заняття у програму було включено фітнес белліденс, із тринадцятого - гоугоу. Починаючи із другого етапу (набуття фізичної форми), у програму занять уключались більш інтенсивні види: афро-денс, рок-н-рол аеробіка, диско-денс. Крім того, елементи танцювальної аеробіки поєднувались зі степ-аеробікою, що підвищувало як навантаження, так і координаційну складність занять.

Перед початком занять із використанням спеціального обладнання (гантелі, бодібари тощо) 3 тими, хто займаються, проводили певну підготовчу роботу. Розміщення обладнання 3 потрібною вагою по периметру залу неподалік від себе допомагало підтримувати на необхідному рівні щільність заняття та попереджувати зниження навантаження в його середині. Тобто за потреби ті, хто займаються, брали завчасно підготовлене обладнання для виконання вправ, не витрачаючи час на пошук, наприклад, гантелей із необхідною вагою чи іншого інвентарю.

Варто зазначити, що залежно від етапу (втягувальний, набуття або підтримання фізичної форми та активного відпочинку) підбирався музичний супровід для занять. Так, під час занять на втягувальному етапі темп музичного супроводу був у межах 126-150 уд./ хв, на етапі набуття фізичної форми - в межах 126-156 уд./ хв, на етапі підтримання фізичної форми - в межах 126-156 уд./ хв. та на етапі активного відпочинку - коливався від 126 до 148 уд./ хв.

Розподіл та тривалість блоків аеробного спрямування, силового та ментального фітнесу на різних етапах проведення занять був різним, що пов'язано 3 різностороннім впливом на організм тих, хто займаються. Так, згідно $з$ даними Е.Б. Мякинченко, М.П. Шестакова [1], аеробні вправи, які виконуються протягом тривалого часу, зміцнюють серцево-судинну систему, підвищують витривалість та сприяють спалюванню жирових клітин. Вправи силового блоку впливають на розвиток силової витривалості, поліпшення аеробних силових можливостей м'язів та зменшення жирового прошарку [2]. Заняття ментальним фітнесом покликані розвивати гнучкість та рухливість у суглобах, сприяють концентрації уваги, зняттю стресових напружень та відновленню організму. Враховуючи вищезазначене, було побудовано комплексну програму 3 оздоровчої аеробіки та ментального фітнесу, яка охоплює три види режимів виконання вправ.

Таким чином, протягом упровадження комплексної програми з оздоровчої аеробіки та ментального фітнесу спостерігалась тенденція зміни тривалості компонентів різного спрямування. Це сприяло формуванню зацікавленості жінок до занять та поліпшенню показників фізичної підготовленості жінок першого зрілого віку [12].

\section{Висновки.}

Установлено популярні види оздоровчої аеробіки: степ-аеробіка, фітбол-аеробіка, скульптура тіла, латина (сальса) та пол-денс. Популярними видами ментального фітнесу опитувані визначили фітнес-йогу, пілатес та стретчинг.

Побудовано комплексну програму занять 3 оздоровчої аеробіки та ментального фітнесу у співвідношенні засобів на 74\%/26\%.

Обгрунтовано комплексну програму занять 3 оздоровчої аеробіки та ментального фітнесу, яка передбачає заняття три рази на тиждень тривалістю 60 хв.

\section{ЛІТЕРАТУРА}

1. Аэробика. Теория и методика проведения занятий : учеб. пособ. для студентов вузов физической культуры / под ред. Е.Б. Мякинченко, М.П. Шестакова. Москва : СпортАкадемПресс, 2002. 304 с.

2. Теоретико-методические основы организации и проведения физкультурно-оздоровительной деятельности с населением Республики Молдова. Стратегическое направление: восстановление человеческого, природного ресурса, информации об устойчивом развитии : монография / О.Е. Афтимичук, И.Д. Мруц, А.Г. Полевая-Секэряну. Кишинев : Valinex SRL, 2013. 206 с.

3. Бибик Р.В. Анализ современных оздоровительных технологий используемых в процессе физического воспитания женщин первого зрелого возраста. Физическое воспитание студентов творческих специальностей. Харьков. гос. акад. дизайна и искусств. Харьков, 2008. № 4. С. 16-27. 
4. Глоба Г.В. Інноваційна система фізичного виховання школярів з використанням аеробних технологій : автореф. дис. на здобуття наук. ступеня канд. наук з фізичного виховання і спорту : спец. 24.00 .02 «Фізична культура, фізичне виховання різних груп населення». Харків, 2007. 20 с.

5. Губарєва О.С. Розвиток педагогічної технології в оздоровчих видах гімнастики : автореф. дис. на здобуття наук. ступеня канд. наук з фізичного виховання і спорту : спец. 24.00 .02 «Фізична культура, фізичне виховання різних груп населення». Київ, 2001. 21 с.

6. Новые фитнес-системы (новые направления, методики, оборудование и инвентарь) : учеб. пособ./ В.Ю. Давыдов, А.И. Шамардин, Г.О. Краснова. Волгоград : Издательство ВолГУ, 2005. 284 с.

7. Дуліба О.Б. Оцінка і оптимізація розумової і фізичної працездатності студенток засобами ритмічної гімнастики : автореф. дис. на здобуття наук. ступеня канд. біологічних наук : спец. 03.00.13 «Фізіологія людини і тварин». Львів, 2000. 17 с.

8. Козій Т.П., Тарасова О.О. Вплив фізичних навантажень під час занять аквааеробікою та шейпінгом на динаміку антропометричних показників жінок. Вісник Чернігівського національного педагогічного університету. Серія : Педагогічні науки. Фізичне виховання та спорт. 2012. С. 96-101.

9. Лядська О.Ю. Організаційно-методичні основи оздоровчого тренування з фітболом жінок першого зрілого віку гімнастики : автореф. дис. на здобуття наук. ступеня канд. наук з фізичного виховання і спорту : спец. 24.00 .02 «Фізична культура, фізичне виховання різних груп населення». Дніпропетровськ, 2011. $20 \mathrm{c}$.

10. Мороз О.О. Корекція маси та складу тіла жінок 21-35 років засобами оздоровчого фітнесу : автореф. дис. на здобуття наук. ступеня канд. наук з фізичного виховання і спорту : спец. 24.00.02 «Фізична культура, фізичне виховання різних груп населення». Київ, 2011. 21 с.

11. Оздоровча аеробіка. Спортивно-педагогічне вдосконалення : навч. посіб. / С.В. Синиця, Л.Є. Шестерова, Т.О. Синиця. Львів, 2018. 236 с.

12. Зміни фізичної підготовленості жінок першого зрілого віку під впливом занять 3 оздоровчої аеробіки / Т.О. Синиця, С.В. Синиця, Л.С. Шестерова. Фізичне виховання, спорт і культура здоров'я у сучасному суспільстві. Луцьк, 2015. С. 176-180.

13. Вплив занять фітнес-аеробіки на функціональні показники жінок / О.М. Шишкіна, I.О. Бейгул. Фізичне виховання, спорт і культура здоров'я у сучасному суспільстві : збірник наукових праць. 2014. № 2(26). С. 53-56.

14. Ядвіга Ю.П. Фізичне виховання студентів вищого навчального закладу економічного профілю в період трансформації вищої освіти України в європейський простір : автореф. дис. на здобуття наук. ступеня канд. наук з фізичного виховання і спорту : спец. 24.00 .02 «Фізична культура, фізичне виховання різних груп населення». Київ, 2011. 22 с.

15. The popular activities of health aerobics among women of Ukraine / T. Synytsa, L. Shesterova, S. Synytsa. Stiinta Culturii Fizice : Chisinau : Editura USEFS, 2014. № 19/3. S. 101-107.

\section{REFERENCES}

1. Miakinchenko E. B., Shestakova M. P. (ed.) (2002) Aerobika. Teoriia i metodika provedeniia zaniatii [Aerobics. Theory and methodology of conducting classes]. Moscow. (in Russian)

2. Aftimichuk O. E., Mrutc I. D., Polevaia-Sekerianu A. G. (2013) Teoretiko-metodicheskie osnovy organizatcii i provedeniia fizkulturno-ozdorovitelnoi deiatelnosti s naseleniem Respubliki Moldova. Strategicheskoe napravlenie: vosstanovlenie chelovecheskogo, prirodnogo resursa, informatcii ob ustoichivom razvitii [Theoretical and methodological foundations of organizing and conducting physical culture and health-improving activities with the population of the Republic of Moldova. Strategic direction: restoration of human, natural resources, information on sustainable development]: monografiia. Kishinev: Valinex SRL. (in Russian)

3. Bibik R. V. (2008) Analiz sovremennykh ozdorovitelnykh tekhnologii ispolzuemykh v protcesse fizicheskogo vospitaniia zhenshchin pervogo zrelogo vozrasta [Analysis of modern health technologies used in the process of physical education of women of the first mature age]. Fizicheskoe vospitanie studentov tvorcheskikh spetcialnostei, no. 4, pp. 16-27. (in Russian)

4. Globa G. V. (2007) Innovatsiina systema fizychnoho vykhovannia shkoliariv z vykorystanniam aerobnykh tekhnolohii [Innovative system of physical education of schoolchildren with the use of aerobic technologies] (Extended abstract of candidate's thesis), Kharkiv. (in Ukrainian)

5. Hubarieva O. S. (2001) Rozvytok pedahohichnoi tekhnolohii v ozdorovchykh vydakh himnastyky [Development of pedagogical technology in health-improving types of gymnastics] (Extended abstract of candidate's thesis), Kyiv. (in Ukrainian)

6. Davydov V. Iu., Shamardin A. I., Krasnova G. O. (2005) Novye fitnes-sistemy (novye napravleniia, metodiki, oborudovanie $i$ inventar) [New fitness systems (new directions, techniques, equipment and inventory)]. Volgograd: VolGU. (in Russian) 
7. Duliba O. B. (2000) Otsinka i optymizatsiia rozumovoi i fizychnoi pratsezdatnosti studentok zasobamy rytmichnoi himnastyky [Assessment and optimization of mental and physical performance of female students by means of rhythmic gymnastics] (Extended abstract of candidate's thesis), Lviv. (in Ukrainian)

8. Kozii T. P., Tarasova O. O. (2012) Vplyv fizychnykh navantazhen pid chas zaniat akvaaerobikoiu ta sheipinhom na dynamiku antropometrychnykh pokaznykiv zhinok [The influence of physical activity during aqua aerobics and shaping on the dynamics of anthropometric indicators of women]. Visnyk Chernihivskoho natsionalnoho pedahohichnoho universytetu. Seriia: Pedahohichni nauky. Fizychne vykhovannia ta sport, pp. 96-101. (in Ukrainian)

9. Liadska O. Yu. (2011) Orhanizatsiino-metodychni osnovy ozdorovchoho trenuvannia z fitbolom zhinok pershoho zriloho viku himnastyky [Organizational and methodical bases of health training with fitball of women of the first mature age of gymnastics] (Extended abstract of candidate's thesis), Dnipropetrovsk. (in Ukrainian).

10. Moroz O. O. (2011) Korektsiia masy ta skladu tila zhinok 21-35 rokiv zasobamy ozdorovchoho fitnesu [Correction of body weight and body composition of women 21-35 years old by means of health fitness] (Extended abstract of candidate's thesis), Kyiv. (in Ukrainian)

11. Synytsia S. V., Shesterova L. Ye., Synytsia T. O. (2018) Ozdorovcha aerobika. Sportyvno-pedahohichne vdoskonalennia [Health aerobics. Sports and pedagogical improvement]. Lviv. (in Ukrainian).

12. Synytsia T. O., Synytsia S. V., Shesterova L. Ye. (2015) Zminy fizychnoi pidhotovlenosti zhinok pershoho zriloho viku pid vplyvom zaniat $\mathrm{z}$ ozdorovchoi aerobiky [Changes in the physical fitness of women of the first adult age under the influence of health aerobics classes]. Fizychne vykhovannia, sport i kultura zdorov'ia u suchasnomu suspilstvi, no. 3, pp. 176-180. (in Ukrainian)

13. Shyshkina O., Beihul I. (2014) Vplyv zaniat fitnes-aerobiky na funktsionalni pokaznyky zhinok [Influence of fitness aerobics classes on women's functional indicators]. Fizychne vykhovannia, sport i kultura zdorov'ia u suchasnomu suspilstvi, no. 2 (26), pp. 53-56. (in Ukrainian)

14. Yadviha Yu. P. (2011) Fizychne vykhovannia studentiv vyshchoho navchalnoho zakladu ekonomichnoho profiliu $v$ period transformatsii vyshchoi osvity Ukrainy v yevropeiskyi prostir [Physical education of students of higher educational institution of economic profile in the period of transformation of higher education of Ukraine into the European space] (Extended abstract of candidate's thesis), Kyiv. (in Ukrainian)

15. Synytsa T., Shesterova L., Synytsa S. (2014) The popular activities of health aerobics among women of Ukraine. Stiinta Culturii Fizice, no. 19/3, pp. 101-107. 